\title{
Ergonomics, development and
} sustainable work: a look for worker's health

\author{
Ergonomia, desenvolvimento e trabalho \\ sustentável: um olhar para a saúde do trabalhador
}

\author{
Renato José Bonfatti', Luiz Carlos Fadel de Vasconcellos', Aldo Pacheco Ferreira'
}

\begin{abstract}
Background: The Brundlandt Report (Our Common Future), from 1987, provided just a generic notion of sustainable development, leaving to the political, academic and social milieus the formulation of the technical foundations of sustainability. Within this context, category workers' health was neglected. Objective: The present paper discusses the central relevance of work and its relationship to health for the development of sustainability as anchored in the respect for the life and health of workers. Methods: Based on the qualitative scientific paradigm and the dialectical method, the theoretical and empirical research conducted in the presented study adopted an epistemological perspective grounded on three basic principles: constructive nature of interpretative knowledge, interactive nature of the research process and significance of singularity as a level of knowledge production through a dialogical process. Results: Based on the analysis performed, subject workers' health in its relation to sustainable development was subjected to an epistemological discussion. Conclusion: To fully substantiate this notion, the idea of sustainable development implies a thorough involvement of ergonomics and other fields of knowledge related to work.
\end{abstract}

Keywords I sustainable development; ergonomics; occupational health.

RESUMO | Contexto: O Relatório Brundlandt (Nosso Futuro Comum), de 1987, ao enunciar o conceito genérico de desenvolvimento sustentável, deixou para os sucessivos formuladores nos campos político, acadêmico e social a produção das bases técnicas da sustentabilidade. Nestas, a categoria saúde do trabalhador foi negligenciada. Objetivo: No presente texto discutiu-se a relevância central que o trabalho e sua relação com a saúde têm na constituição de uma sustentabilidade amparada no respeito à vida e à saúde dos que trabalham. Métodos: Baseada no paradigma científico qualitativo e no método dialético, a pesquisa teórica e empírica desenvolvida neste trabalho deu-se a partir da perspectiva da epistemologia, a qual se apoia em três princípios básicos: o caráter construtivo interpretativo do conhecimento, o interativo do processo de pesquisa e a significação da singularidade como nível da produção do conhecimento, por meio de um processo dialógico. Resultados: Diante das análises, procedeu-se a uma discussão epistemológica sobre a saúde do trabalhador perante o desenvolvimento sustentável. Conclusão: Foi identificado que o ideário do desenvolvimento sustentável implica o envolvimento visceral da ergonomia e das demais áreas do conhecimento comprometidas com o trabalho, de forma a alicerçar o conceito em sua plenitude.

Palavras-chave I desenvolvimento sustentável; ergonomia; saúde do trabalhador.

Study performed at Sergio Arouca Public Health National School (Escola Nacional de Saúde Pública Sergio Arouca — ENSP), Oswaldo Cruz Foundation (FIOCRUZ) Rio de Janeiro (RJ), Brazil.

'Sergio Arouca Public Health National School (Escola Nacional de Saúde Pública Sergio Arouca - ENSP), Oswaldo Cruz Foundation (FIOCRUZ) - Rio de Janeiro (RJ), Brazil. DOI: 10.5327/Z1679443520170006 


\section{INTRODUCTION}

Work is defined as a procedure of material interaction between man and nature, in which through his own action the former intentionally acts on elements of the latter, thus transforming and making them useful for human life. Upon acting on materials, man imposes his conscious plans on them, thus subjecting them to his will ${ }^{1,2}$.

The physician Gro Harlem Brundtland, who has a master degree in public health and served as Prime Minister of Norway, was invited by the Secretary-General of the United Nations (UN) in 1983 to establish and chair the World Commission on Environment and Development. The reason to choose Brundtland was the pioneering work she was doing at that time, in which health was approached beyond the scope of medicine to include actions related to the environment and human development.

The UN-created World Commission on Environment and Development released Our Common Future, also known as the Brundlandt report. This report gave a definition of sustainable development: "Sustainable development is development that meets the needs of the present without compromising the ability of future generations to meet their own needs ${ }^{3}$."

As a generic concept, its consolidation and UN-sponsored legitimation led to its adoption. However, with different understandings within the context of public and private policies in the various countries, knowledge production by global teaching and research institutions, and of social organizations across the world, with their inexhaustible multiple approaches to this subject. Analysis of the successive formulations of the concept within all these contexts, which origin can be traced back to the Brundlandt Report, unequivocally shows that variable work was not included in the concept of sustainability. Such patent absence of work as such and in its meaningful relationship to health, workers' health in particular, characterizes the typical object of the field Boaventura de Souza Santos ${ }^{4}$ designated as sociology of absences:

It is investigation that seeks to demonstrate that which does not exist, as a fact, is actively produced as such, i.e., as a non-believable alternative to that which exists. Its empirical object is considered to be impossible in the light of the conventional social sciences, and thus its very formulation represents a break with them.

Neglect of workers' health - either in singular, i.e., as a field of knowledge ${ }^{2}$, or in plural (the health of workers) and ontological and universal expression of the capital-labor relationship ${ }^{5}$ - deals a fatal blow to the notion of sustainable development. The reason is the omission of the preservation of the life and health of the individuals who produce consumer goods across the planet.

The overall goals of the present text were to review the place of work within the notion of sustainability ${ }^{6}$ and to develop an epistemological approach consistent with the ethos of sustainable development. As such, these goals demand consideration of fields of knowledge directly related with workers' health, among which ergonomics stands out, to ground reflections and practices on ideas intrinsic to the notion of sustainability. And also as a function of its intimate relationship with the job positions that originate the activities that set the teleological tone for productive processes.

The problem posed by the environment emerges as a new challenge to those who incessantly look for dogmatic results, the outcome of which is lack of good sense and focus on technicity. The result is an epistemological obstacle that goes much beyond the domain conditions of the theoretical-scientific rationality. As a function of the environmental and social barriers derived from this process, and of an epistemological lack of reappraising criticism, the notion of epistemology developed within the new paradigms for the dichotomous man/nature relationship is fully justified, inasmuch as the current approach to knowledge is increasingly technicist and reductionist. In other words, it involves an oversimplification of the object of study, while philosophical-scientific aspects are not given their proper value ${ }^{7}$.

\section{METHODS}

In essence, epistemology is the critical study of principles, hypotheses and results of the various sciences to determine their logical origin, value and objectivity ${ }^{7}$. Within the sphere of epistemology, scientific objects are continuously constructed and the boundaries of the 
problems related with investigation determined. In consequence, discourse parameters, paradigms and the criteria of scientificity that orient the full process of investigation are constantly reformulated ${ }^{8}$.

Based on the qualitative scientific paradigm ${ }^{9}$ and the dialectical method ${ }^{10}$, the theoretical and empirical research performed in the present study was conducted from the perspective of epistemology ${ }^{7,11}$, which is grounded on three basic principles:

- the constructive and interpretative nature of knowledge;

- the interactive nature of the research process;

- the relevance of singularity as a level of knowledge production through a dialogical process.

Thus we approached the epistemological conceptual construction within an interdisciplinary framework involving aspects of ergonomics, development and sustainable work. The present article was organized in four parts:

- the first part describes the current state of health at work;

- the second part describes the challenges to the developmental model within the context of sustainable evolution;

- the third part analyzes the proximity of ergonomics to sustainable work;

- the fourth part discusses the reach of and challenges to sustainable work.

\section{HEALTH AT WORK: FACTS AND DATA}

Set within a developmentalist macroeconomic management process for many years now, Brazilian workers cannot see any improvement of their health at work ${ }^{12}$. Very much the opposite, factors such as exacerbation of the process of loss of social rights, precariousness and outsourcing supported by new legislation passed by a heavily conservative congress, and further complicated by a possible economic recession with consequent increase of unemployment - strongly contribute to create an unfavorable and gloomy scenario.

More than ever, such context points to the need to broaden the scope of ergonomics and to bring it more and more close to the core of the political-social debate on the health-work relationship. Inclusion of ergonomics, especially of its aspect of surveillance, into public policies for workers' health is crucial, involving the participation of academia, services, social movements and trade unions. Increasing the inclusion of ergonomics at the various levels of training, undergraduate and graduate courses in the fields of health, engineering and management is also relevant. The wealth of knowledge that ergonomics has already gathered to configure work processes likely to lead to safer and more comfortable production, must now "spill over" to society at large and be appropriated by it for the sake of sustainability-compatible development also in the world of work.

As is known, the degree of civilization of a country might be established based on the level of exploitation of its workforce and neglect of its children. A country can only be rated civilized when it protects and educates its children and protects and defends its workforce.

The end of the Cold War and the triumph of economic liberalism through - the now well consolidated - globalization posed a dilemma to the market economy that the various countries have failed to solve: unrestricted market freedom to promote social justice and the obvious inability to achieve this goal ${ }^{13}$.

In the second half of the past century, Polany ${ }^{14}$ called the attention to the satanic market mill as something able to grind everybody - workers and entrepreneurs - and the whole of society, just as flour is ground. Not by chance that the concentration of wealth is accelerating worldwide.

The British non-governmental organization Oxfam recently released the latest edition of its study on the global concentration of wealth. The highly suggestive title of this study is "An Economy for the $1 \%{ }^{15}$." The gap between the rich and the poor is wider than ever. The Credit Suisse bank recently disclosed that the richest $1 \%$ of the global population have more combined wealth than the rest of the world together.

The 62 richest individuals currently own as much wealth as the poorer half of the world population. This means that the average wealth of this group (G-62) is more than 56 million times the average income of the poorer half of the world population. Less than 1,000 individuals (946, including 16 Brazilians) accumulate 3.5 trillion dollars. Nine and half million people (less than $0.02 \%$ of the world population) concentrate more than half the global gross domestic product (GDP) - 66 trillion dollars. This a staggering scenario, facing which people - including scholars shrug their shoulders, as if it were something that does not 
concern them, being nothing but a mere statistical curiosity. How to raise subject sustainable development in such a world? What is the role of the ones who are still able to react with indignation?

Within the world of work, the gap between average workers and the ones at the top is increasing fast. While the salary of many workers stagnated, the one of workers at the top increased vertiginously. The salary of the CEOs of the largest North-American companies increased by more than half (54.3\%) since 2009 , while the one of the common employees remained practically the same. The salary of the CEO of the largest information technology company in India is 416 times higher than the one of the average employee ${ }^{15}$.

We cannot say we do not know why poverty, hunger, wars, urban violence and the planet's devastation are increasing. The essential problem is the unsolved economic situation made even worse by the market economy model. The reason is simple: the market lacks ethics. As a result, for being strictly grounded on the market economy model, also economic globalization lack ethics: human, social and political ethics.

Boaventura de Souza Santos ${ }^{16}$ calls the attention to the fact that:

Among all the versions of capitalism [developed] in the past 100 years, the current neoliberal version is proving to be the most destructive on both the social and the political levels. It enters the life of citizens under the shape of a crisis, which it simultaneous creates and solves. It imposes as solutions for this crisis that which are problems for the overwhelming majority of citizens (impoverishment, unemployment, social inequality, precariousness, lack of positive expectations, the ideology of autonomy hiding the abject submission of the weakest, disciplinarian and repressive governments) and (on the other hand) it stigmatizes as crisis-causing problems that which are solutions for the overwhelming majority of citizen (social rights, human safety, decent work, dignified life, collective responsibility, protective governments).

Without losing sight of the more global expectations for true human development - currently very poor in terms of income distribution, equity and humanism, especially in Brazil - in the present study we focused on subject health at work according to the principles of the ethics of labor, of the production system and of development. These three types of ethics might (and should) be soundly articulated to a humanistic, social and political moral principle.

The ethics of the working conditions, influenced by a humanistic perspective, was born together with the Industrial Revolution, when it became clear that work had ceased to be a source of life to become a fast-track passport to death ${ }^{17}$.

As a result, the earliest regulations were formulated to slow down the ability to extract from workers strength beyond the human boundaries. More than two hundred years went by: what do we find?

The latest data on work-related health conditions are alarming and discouraging. Here we had resource to the statistical bulletin published in 2015 by Fundacentro ${ }^{18}$, based on data from the National Health Survey (Pesquisa Nacional de Saúde - PNS) and the Social Security Statistical Yearbook (Anuário Estatístico da Previdência Social - AEPS) for 2013. The number of work accidents (WA) reported by PNA is an impressive 4,948,000, in overt discrepancy with the one described in AEPS, 717,911 . Such divergence is due to the fact that PNA is based on direct data from interviews performed within the National Household Sample Survey (Pesquisa Nacional de Amostra Domiciliar - PNAD/IBGE) and the source of AEPS are WA notified via Work Accident Reports (WAR) or selected by the DATAPREV system through the Epidemiological Technical Nexus (Nexo Técnico Epidemiológico - NTEP) which crosschecks data from the National Classification of Economic Activities (Classificação Nacional de Atividades Econômicas — CNAE), Brazilian Classification of Occupations (Classificação Brasileira de Ocupações - CBO) and the $10^{\text {th }}$ revision of the International Statistical Classification of Diseases and Related Health Problems (ICD-10).

\section{ADVANCES IN SUSTAINABLE DEVELOPMENT: CHALLENGES}

No sustainable production process can exist without respect for the life and health of workers. The current 
advocates of sustainability forgot that work is an inducer of production, and thus, also of development.

If sustainable development is based on the restructuration of production systems, the kernel of which is grounded on work processes and environments ${ }^{19}$, then the fact that the preservation of work as such is not given its due attention, and that labor loses focus in developmentalism theory, practice and policies, seems extremely contradictory ${ }^{7}$. Therefore, criticism of the development model, together with its mechanisms of growth, in which sustainability is always in the rearguard of the economic guidelines, is needed. Yet, there is an aspect of sustainability that tells more about our convictions on the relationship between health and work: the sustainability of development begins in the world of work.

The relationship between health at work and sustainable development has strategical and political relevance which has not been duly appreciated. The management of hazards inherent to the production process, differences between the prescribed and effectively done work in everyday or emergency situations - as seen in the environmental disasters studied by ergonomics ${ }^{20}$ - and the close relations of workers to their workstations call the attention to the need to reformulate the organization of work and the production processes toward sustainable labor.

Hvid and Lund ${ }^{21}$ already pointed to this problem, upon observing that academic discussions on sustainability do not give their due relevance to work - now and in the future. The vast knowledge developed on sustainability, both theoretical and political, includes a confuse range of interpretations lacking methods to improve their understanding: "The many different interpretations of sustainable development are confusing. To help make sense of them we are suggesting a mapping methodology based on combining environmental and socioeconomic issues" 22 .

In any case, work is not considered as core epistemic category in most such interpretations. In the best of cases, we might find one or another sparse mention to it, without its due consideration. The relationship between health and work is the locus of the essence of the similarity between life itself and the development of humankind in its most primitive version. Dilapidation of health and life is directly evidenced from within labor systems, as a function of the past, present and future organization of productive processes.
The health-work relationship also clearly shows that production systems - from the simplest to the most sophisticate ones - have a socio-technical nature, and thus do not attribute value to health and life. As a result, they are incoherent with the idea of global sustainability. On these grounds, we might safely assert that to neglect work as the primary object of sustainable development is to deny the very soul of this notion, if this expression might be permitted. The argument becomes clearer when one considers the production chain.

The production chain of steel includes very different working conditions. On the one hand there are steel companies certified according to international standards, on the other, the precariousness of artisanal coal yards, involving intensive and predatory use of forest resources, exploitation of labor under subhuman conditions - including children and adolescents and use of rudimentary technology $y^{23}$.

The behavior of companies, oriented by a notion of sustainable development that does not include labor, becomes apparently modernized through their concern with environmental pollution attuned to the notion of sustainability. Yet, at the same time, they "maintain medieval standards of exploitation, harassment and disrespect in regard to workers, the measure of which is becoming increasingly more difficult to calculate?'.

This is why the inefficacy of inclusive workers' health policies incorporated into the environmental and sustainable development agenda legitimates such behavior. As Rigotto ${ }^{24}$ stated:

lack of strategies for workers' health care (...) might be characterized as a strategy of denial, established to result in the hiding of environmental and health conflicts resulting from the ongoing process of development. When the service network is not fit to detect the harm caused by work and the environment on the health of the population (...) When the ill effects are not recognized (...) When public policies close their eyes to these problems, the government excludes them from the priorities in the field of health, which hinders their visibility to society: in the media, in the negotiation 
agenda between workers and employers, among subjects of research.

Although attempts at approximating sustainable development and labor were made, especially from the perspective of workers' health, they did not suffice to change the direction of sustainability policies, even when originated in institutions with "political pedigree." This is the case of the recommendation formulated by the World Health Organization (WHO) in its $55^{\text {th }}$ World Health Assembly (agenda item 13.3, 18 May 2002: Health and sustainable development) which urges member states to

(... ) to adopt policies that create healthy workplaces, protect workers' health and, consistent with national and international law, prevent transfer of hazardous equipment, processes and materials $(\ldots)^{25}$.

Here we might infer that the approach of ergonomics, for looking deep into the recesses of labor for the sake of its improvement, might be the decisive factor for the inclusion of sustainable work into policies for development. Wisner ${ }^{26}$ already pointed to this fact, when on his analysis of the accident at Bhopal listed a series of events preceding the event:

From the workers' perspective, the situation was no less dangerous. The management favored the departure of engineers and operators through compensations. Half the technicians and most qualified workers had left the company (...). The manpower for the most important control stations at the plant was reduced. The situation was already extremely bad in 1982. The plant had prepared a "Safety Week." Ten accidents occurred along the[se] seven days, and on the seventh, when the week was to close with a ceremony, three accidents occurred, which compelled the management to cancel the party. (...) There was one single operator at the MIC [methyl isocyanate] control room, who was unable to monitor the 70 indicators in the case of an emergency.

The workers' competence and knowledge, their representations on the management of hazards and their technical skills to improve the work systems were not considered in the organization of the production processes. In addition, also other situations contributed to the disaster, such as relentless persecution of trade union organizers claiming for improvement of maintenance, training, etc., and the authorities' carelessness, the countless warnings notwithstanding ${ }^{27}$.

From the political, epistemological and ethical perspectives, sustainable development and sustainable work are inseparable. According to Mattos et al..$^{28}$ :

Most companies do not recognize the existence of environmental problems and hazards for groups of workers and the community, and further hinder the recognition of trade union organization at the workplace and in the exercise of the basic rights of workers. (... ) The access of workers to these data and their organization at the workplace might enable a discussion of the production process, the responsibility of companies for damage and already present hazards, the right to refuse to work at high-risk workplaces and situations and changes in work environments. In this regard, improvement of the working conditions is of public interest, much beyond the context of production enterprises and the locations where they produce their goods and services, and also their problems.

\section{ERGONOMIC AND SUSTAINABLE WORK: PROXIMITY}

The scope of ergonomics became considerably broader when it included Bertalanffy's systems theory and sociotechnics into the study of organizations ${ }^{29}$. From that moment onward, organizations came to be seen as systems composed of social and technical subsystems, which interact in an integrated (not dissociated) manner. The perspective of work as a set of juxtaposed routine and individual tasks was forsaken, to begin to be considered as a system of activities. In addition, the organizational group, and no longer the individual, became the main unit of analysis ${ }^{30}$.

One of the core ideas of sociotechnics is the one that became known as joint optimization principle. It points to 
the fact that the technical systems influence and impose demands on the social systems, whence the efficacy of the full production system depends on the response capacity of the latter to satisfy the former's requirements. In some Nordic countries, the sociotechnical method was used as a part of the efforts to implement a global project of democratization of workplaces ${ }^{31}$.

In the last decades of the $20^{\text {th }}$ century, the theoretical formulations of ergonomics continued to expand in order to broaden its scope. Within this context, a new current emerged, which seeks to overcome the point of view of so-called microergonomics, the focus of which is on specific aspects of workstations. Differently, macroergonomics, or organizational ergonomics, is concerned with the optimization of sociotechnical systems, including their organizational, political and process structure ${ }^{32}$. The study of the components of the work system - workstation, environment and machines, tasks and activities - gains in meaning when their interfaces with organizations are taken into account.

As an another attempt to broaden its scope, ergonomics even reached to anthropotechnology, which deals with the problems raised by the transfer of technology from industrially developed to developing countries ${ }^{26}$. The methodology used in anthropotechnology is based on a complex analysis performed before the onset of the technology transfer process. Such analysis involves in-depth studies of the geographical and economic characteristics of the destination of the technology to be transferred. They also comprise studies which consider trade and financial boundaries, in addition to paying thorough attention to the social tissue, with emphasis on local health conditions and cultural aspects.

In addition to its current broader scope, ergonomics is characterized by its transverse position vis-à-vis the knowledge needed to create sustainable work. This type of knowledge needs to be incorporated into the initiatives for surveillance of work environments and processes, backed by the government as a part of its role of protector, at the various levels. And especially in regard to workers' health surveillance within the Unified Health System (Sistema Único de Saúde - SUS) given its potential capacity to expand the scope of its actions via the Workers' Integrated Health Care National Network (Rede Nacional de Atenção Integral à Saúde do Trabalhador - RENAST) $)^{33,34}$.
Ways to accelerate the process of inclusion of ergonomics within society need to be thought over, to broaden the scope of academic training mainly in the fields of health, engineering and management. Similarly, training should be articulated with social and trade union movements through forums and courses in order to give rise to larger communities of peers linking academia, services and trade unions together ${ }^{35}$.

Might the activity of ergonomic consultants at companies alone - its acknowledged usefulness notwithstanding influence this context? Restriction of ergonomics to consulting services creates competition islands which might conspire against the breadth of the scope we believe to be necessary for the development of sustainable work. Ergonomic consultancy should also embrace the perspective of breaking through isolation to broaden the scope of negotiation in the establishment of demands, and invariably incorporate the workers' representations, intersectorality and interdisciplinarity.

We believe that the achievement of sustainable work depends on the engagement of all the actors likely to intervene in work processes and environments, as is the case of ergonomists. Contrariwise, we will remain as accomplices to inequality.

\section{REACH AND CHALLENGES TO SUSTAINABLE WORK}

Just as the classic concept of sustainability is related to the preservation of life in the planet, sustainable work is the one that preserves life in the "work planet," or as is usually designated, the world of work. Reflections within such wide and complex perspective require addressing several variables of approach ${ }^{36}$. As was shown, there is not any systematized discussion on this subject, whence the present considerations involve several dimensions: epistemological, legal, political, economic, ethical, technical and operational.

An epistemic framework for sustainable works requires broad-scoped criticism of the production of knowledge on sustainability as a whole. Then, the idea that the planet's spatial configuration also includes the "work planet" is an epistemological urgency that has not yet been systematically recognized within the context of academic research. In this 
regard, ergonomics, as one of the fields of knowledge that contribute to transform labor, is in debt to this endeavor. Systematic survey and critical analysis of the theoretical production under such sharp approach still remain to be performed. Then, a revision of the process of knowledge production as such reaffirms the need to broaden the scope of ergonomics in the light of complexity, sociotechnics and anthropotechnology, among other challenges.

As concerns the legal dimension, we stress, particularly in regard to the Brazilian case, the constitutional principle that ensures health as a right to all and a duty of the government, including workers' health, as stated in article 200 of the Constitution ${ }^{37}$. Yet, constitutional indolence in the application of this principle has delayed the development of a stronger attitude in defense of health at work. Turning their back on the Constitution is not a "privilege" to which some special groups are entitled, such as law operators, health care, labor and social security managers, and in the case closest to our interest, professionals involved in this subject, as, e.g., the ergonomists. More organic integration and articulation with workers' health, and greater participation in public health actions in defense of health at work are wanting in ergonomics, understood as a field of action within the world of work.

Differently, upon addressing the technical dimension, we come very close to the very field of action of ergonomics. Indeed, ergonomists finds in the universe of techniques the means to make work sustainable. Some of the more advanced pieces of labor legislation, Regulatory Standard no. 17 (RS 17) and Administrative Rule no. 3.214/1978 ${ }^{38}$, emphasize that technical approaches aiming at intervening on work processes and environments should adjust work to the psychophysiological characteristics of workers, thus contributing to the preservation of their health. However, even though RS 17 is mandatory since 1992, and received appendices that improved it, the overwhelming majority of entrepreneurial organizations do not comply with it. In addition to indolence in the compliance with the Federal Constitution as concerns workers' health, the neglect of sub-constitutional legislation evidences the degree of the lack of interest in the application of technical approaches to improve the working conditions.

In the case of Brazil, the political dimension is the one that best portrays the problems associated with the implementation of sustainable work. Configured within patrimonialism, clientelism and cronyism, the Brazilian political representation brings representatives of a retrograde version of capitalism - the heirs of Coronelismo and coffee barons - into the political arena. As a rule, green-and-yellow capitalism considers the labor rights, including the one to health at work, as either benefits or benevolent concessions, or superfluous expenses which place an onus on capital. The current debate on the flexibilization of labor laws, including the proposal for negotiation to prevail over legislation, is a faithful portrait of this hard-to-deal-with dimension. The perception that a submissive trade union movement is an accomplice to such type of capitalism predatory for health increases the levels of tension and conflict. Hence, understanding sustainable work as an arena of political struggle helps recasting the role of its advocates.

\section{CONCLUSION}

In an oversimplified analogy to environmental preservation, one might say that investment in sustainable economies involves costs that penalize capital at the expense of economic development. Nothing could be further from the truth. To approach the economic dimension of organizations from the financial perspective of balance sheets and immediate costs is as flawed as failing to consider the economic parameters of the costs of work accidents in Brazil, which also include disease. The expenses with the replacement of operators, man-hour losses, absenteeism, lawsuits and loss of market image and credibility, among other variables, are economic aspects passed over in the financial planning of organizations as a whole.

The complex interaction of factors that leads to the comprehension of what we understand as sustainability in the present time points to an unfinished notion, which, as was shown above, banishes work as such from its scope. Upon considering labor as the very heart and foundation of a notion taken back to an epistemological level coherent and respectful of work, as the fundamental activity in the production process no matter which, we evidenced a reluctant absence of object work in the current literature on sustainability.

Finally, assuming the operational dimension as the one that might set the tone for real-time concrete actions aiming 
at making work sustainable, one needs to ponder on some key-ideas in this regard:

- interdisciplinarity;

- intersectorality;

- action research;

- health surveillance;

- participatory democracy.
Facing the complexity of the world of work and inasmuch as it sets sustainable work as goal image, ergonomics needs to break away from its lonely path of action. This is the context to approach the Brazilian health system so that, as a part of our mission to defend the health of workers as a human right, we might succeed in including sustainable work in the development agenda.

\section{REFERENCES}

1. Organisation Mondiale de la Santé. Vieillissement et capacité de travail. Rapport d'un Groupe d'étude de l'OMS. Genève: OMS; 1993. [Série de rapports techniques $n$. 835].

2. Minayo Gomez C, Machado JMH, Pena PGL.Saúde do Trabalhador na Sociedade Brasileira Contemporânea. Rio de Janeiro: Fiocruz; 2011.

3. Brundtland Bulletin. Comissão Mundial sobre Meio Ambiente e Desenvolvimento: o nosso futuro comum. New York: Universidade de Oxford; 1987.

4. Santos BS. Para uma sociologia das ausências e uma sociologia das emergências. Rev Crít Ciênc Sociais. 2002;63:237-80.

5. Souza DO. A saúde na perspectiva da "ontologia do ser social". Trab Educ Saúde. 2016;14(2):337-54.

6. Vasconcellos LCF. Saúde, Trabalho e Desenvolvimento sustentável: apontamentos para uma política de estado [thesis]. Rio de Janeiro: Escola Nacional de Saúde Pública Sergio Arouca; 2007.

7. Bachelard G. A epistemologia. Lisboa: Edições 70; 2001.

8. Santos BS. Introdução a uma ciência pós-moderna. $3^{\text {rd }}$ ed. Rio de Janeiro: Graal; 2000.

9. Audi R. Dicionário Akal de Filosofia. Madri: Akal; 2004.

10. Lakatos EM, Marconi MA. Método dialético. In: Lakatos EM, Marconi MA. Fundamentos de metodologia científica. $5^{\text {th }}$ ed. São Paulo: Atlas; 2003. p. 100-6.

11. Stengers I. A invenção das ciências modernas. Rio de Janeiro: 34 Ed.; 2003.

12. Costa D, Lacaz FAC, Filho JMJ, Vilela RAG. Saúde do Trabalhador no SUS: desafios para uma política pública. Rev Bras Saúde Ocup. 2013;38(127):11-30.

13. Smith A. A riqueza das nações. São Paulo: Abril Cultural; 1983.

14. Polany K. A grande transformação: as origens de nossa época. Rio de Janeiro: Campus; 1980.

15. Oxfam. Uma economia para o 1\%. [cited Sept 15, 2016] Available at: http://www.oxfam.org.br/noticias/relatorio_davos_2016

16. Santos BS. A cor do tempo quando foge: uma história do presente - Crônicas 1986-2003. São Paulo: Cortez; 2014.

17. Vasconcellos LCF, Oliveira MHB. Direitos humanos e saúde no trabalho. In: Brasil. Ministério da Saúde. Fundação Oswaldo Cruz, Núcleo de Estudo em Direitos Humanos e Saúde Helena Besserman (NEDH). Saúde e Direitos Humanos. ano 4, n. 4, 2007. Brasília: Editora do Ministério da Saúde; 2008.

18. Maia ALS, Saito CA, Oliveira JA, Bussacos MA, Maeno M, Lorenzi RL, et al. Acidentes de trabalho no Brasil em 2013: Comparação entre dados selecionados da Pesquisa Nacional de Saúde do
IBGE (PNS) e do Anuário Estatístico da Previdência Social (AEPS) do Ministério da Previdência Social. Boletim Fundacentro de Estatísticas de Acidentes de Trabalho, 2015. [cited Jan 24, 2017] Available at: http://www.fundacentro.gov.br/arquivos/projetos/ estatistica/boletins/boletimfundacentrolvfinal.pdf

19. Sachs I. Desenvolvimento: includente, sustentável, sustentado. Rio de Janeiro: Garamond; 2004.

20. Wisner A. A inteligência no trabalho. São Paulo: Fundacentro; 1993.

21. Hvid H, Lund HL. Sustainable work: concepts and elements of practice. J Transdiscipl Environ Studies. 2002;1(2):1-20.

22. Hopwood B, Mellor M, O’Brien G. Sustainable Development: mapping different approaches. Sustain Development. 2005;13:38-52.

23. Dias EC, Assunção AA, Guerra CB, Cano Prais HA. Processo de trabalho e saúde dos trabalhadores na produção artesanal de carvão vegetal em Minas Gerais, Brasil. Cad Saúde Pública. 2002;18(1):269-77.

24. Rigotto RM. O "progresso" chegou. E agora? As tramas da (in) sustentabilidade e a sustentação simbólica do desenvolvimento [thesis]. Fortaleza: Centro de Humanidades, Universidade Federal do Ceará; 2004.

25. Asamblea Mundial de la Salud. Salud y desarrollo sostenible. 2002 [cited Sept 15, 2016] Available at: http://apps.who.int/iris/ bitstream/10665/81990/1/ swha5511.pdf

26. Wisner A. La cognition et l'action située: conséquences pour l'analyse ergonomique de travail et l'anthropotechnologie. Association canadieenne d'ergonomie, I: 1-13. Ergonomics. 1994;38:1542-83.

27. Wisner A. Questions épistémologiques en ergonomie et en analyse du travail. In: Daniellou F. (Ed.). L'ergonomie en quête de ses principes - Débats épistémologiques. Toulouse: Octarès; 1996.

28. Mattos UAO, Porto MFS, Freitas NBB. Novas tecnologias, organização do trabalho e seus impactos na saúde, no meio ambiente. Saúde, Meio Ambiente e Condições de Trabalho - Conteúdos básicos para uma ação sindical. São Paulo: Publicação CUT/Fundacentro; 1995.

29. Bowditch JL, Buono AF. Elementos de comportamento organizacional. São Paulo: Thompson Pioneira; 1992.

30. Trist EL. The evolution of socio-technical system. Toronto, Ontario: Ministry of Labor/Ontario Quality of Working Life Center; 1981.

31. Garcia RM. Abordagem sócio técnica: uma rápida avaliação. Rev Adm Empres. 1980;20(3):71-7.

32. Hendrick HW. Organizational design and macroergonomics. In: Salvendy G. (Ed.). Handbook of human factors and ergonomics. New York: John Wiley \& Sons; 1997. 
33. Dias EC, Hoefel MG. O desafio de implementar as ações de saúde do trabalhador no SUS: a estratégia da RENAST. Ciênc Saúde Coletiva. 2005;10(4):817-27.

34. Leão LHC, Vasconcellos LCF. Rede Nacional de Atenção Integral à Saúde do Trabalhador (Renast): reflexões sobre a estrutura de rede. Epidemiol. Serv Saúde. 2011;20(1):85-100.

35. Fórum Intersindical Saúde - Trabalho - Direito. Informação em Saúde do Trabalhador - para que serve se não for para mudar a realidade? 2015[cited Sept 15, 2016];(4). Available at: http://www.forumat.net.br/ at/sites/default//arq-paginas/ boletim_no_4_forum_intersindical_st_rj.pdf

36. Sznelwar LI. O trabalho sob um olhar sustentável - Desafios para os serviços de saúde pública: estudo de caso do Programa Saúde da Família em São Paulo, Brasil. Laboreal. 2009;5(1):38-52.
37. Brasil. Constituição da República Federativa do Brasil. 1988 [cited May 7, 2016] Available at: http://www.senado.gov.br/atividade/ const/ constituicao-federal.asp

38. Brasil. NR 17Ergonomia. [cited Sept 15,2016] Available at: http://acesso mte.gov.br/data/files/FF8080812BE914E6012BEFBAD7064803/ nr_17.pdf

Correspondence address: Aldo Pacheco Ferreira - Fundação Oswaldo Cruz, Escola Nacional de Saúde Pública Sergio Arouca, Departamento de Direitos Humanos, Saúde e Diversidade Cultural - Avenida Brasil, 4.036, sala 905 - Bonsucesso - CEP: 21040-361 - Rio de Janeiro (RJ), Brazil E-mail: aldopachecoferreira@gmail.com 